\title{
PERKEMBANGAN FISIK MOTORIK ANAK USIA SEKOLAH DASAR DALAM PROSES PEMBELAJARAN (STUDI KASUS DI SD MUHAMMADIYAH KARANGBENDO YOGYAKARTA)
}

\author{
Hascita Istiqomah ${ }^{1}$ dan Suyadi ${ }^{2}$ \\ Program Magister PGMI, UIN Sunan Kalijaga Yogyakarta \\ Email: ${ }^{1}$ hascitaistiqomah@gmail.com ${ }_{2}{ }^{2}$ suyadi@uin-suka.ac.id
}

\begin{abstract}
Abstrak: Penelitian ini bertujuan untuk mengetahui perkembangan fisik motorik anak di sekolah Dasar Muhammadiyah Karangbendo. Penelitian ini menggunakan metode kualitatif deskriptif dengan perolehan data berdasarkan teknik observasi, wawancara dan dokumentasi. Subjek penelitian ini adalah para siswa kelas VI A yang terdiri dari 28 orang. Adapun teknik analisis data dalam penelitian ini menggunakan analisis sebelum kelapangan dan analisis di lapangan dengan model Miles and Hubermen yang meliputi data reduction, data display dan conclusion drawing. Berdasarkan hasil penelitian dapat dijelaskan bahwa secara simultan dalam proses pembelajaran terlihat semua siswa memiliki perkembangan fisik motorik yang berbeda-beda dan perkembangan tersebut terus berjalan dan berubah-ubah sesuai dengan kegiatan belajar siswa.
\end{abstract}

Kata kunci: Perkembangan, Fisik Motorik, Anak Usia Sekolah Dasar.

\section{PENDAHULUAN}

Pendidikan adalah proses pengubahan sikap dan tata laku seseorang atau kelompok orang untuk mendewasakan manusia melalui upaya pengajaran dan pelatihan. Sejak dini manusia sudah membutuhkan pendidikan dalam proses perkembangannya menjadi bermain. ${ }^{1}$

Usia rata-rata anak Indonesia saat masuk sekolah dasar adalah 6 tahun dan selesai (lulus) pada usia 12 tahun. Jika merujuk pada pembagian tahapan perkembangan anak, maka anak usia sekolah berada pada dua masa perkembangan, yang pertama yaitu masa kanak-kanak tengah (6-9 tahun), dan yang kedua yaitu masa kanak-kanak akhir (10-12 tahun).

Anak-anak usia sekolah mememiliki karakteristik yang berbeda dengan anak-anak yang usianya lebih muda. Ia senang bermain, senang bergerak, senang bekerja dalam kelompok, dan senang merasakan atau melakukan sesuatu secara langsung. Oleh karena itu, guru sebaiknya mengembangkan proses pembelajaran yang mengaitkan antara permainan

${ }^{1}$ Novan Ardy Wiyani \& Barnawi, Format PAUD Konsep, Karakteristik \& Implementasi Pendidikan Anak Usia Dini, (Jogjakarta: Ar-Ruzz Media, 2012), hlm. 72. 
dengan pelajaran, kemudian guru juga dapat mengusahakan anak berpindah atau bergerak, anak juga diajarkan cara bekerja atau belajar dalam kelompok, serta guru memberikan kesempatan untuk terlibat langsung dalam pembelajaran. ${ }^{2}$

Pemahaman tentang anak merupakan suatu awal keberhasilan dalam pendidikan. Dunia anak merupakan dunia bermain, di saat mereka bermain anak-anak akan menyerap segala sesuatu yang terjadi di lingkungan sekitarnya, sebagaimana yang diungkapkan oleh Maslichatoen bahwa "bermain juga merupakan tuntutan dan kebutuhan yang esensial bagi anak Usia Sekolah Dasar, melalui kegiatan bermain anak akan dapat mencapai tuntutan dan kebutuhan perkembangan dimensi dari motorik, kognitif, kreativitas, bahasa, emosi, sosial, nilai, dan sikap hidup".3

Aspek perkembangan motorik merupakan salah satu aspek perkembangan yang dapat mengintegrasikan perkembangan aspek yang lain. Perkembangan fisik motorik diartikan sebagai perkembangan dari unsur kematangan dan pengendalian gerak tubuh. Perkembangan fisik memiliki peran yang sangat penting bagi kehidupan anak, baik secara langsung maupun tidak langsung. Secara langsung perkembangan fisik seorang anak akan menentukan keterampilan anak dalam bergerak. Sementara secara tidak langsung, pertumbuhan dan perkembangan fisik akan mempengaruhi cara pandang anak terhadap dirinya sendiri dan cara pandang anak terhadap orang lain, perkembangan fisik berjalan seiring dengan perkembangan motorik. Gangguan perkembangan fisik motorik pada usia anak sekolah dasar menjadi kendala tersendiri dalam aktifitasnya, diantaranya, anak akan kesulitan bermain, menulis, menghapus papan tulis dan lain sebagainya. ${ }^{4}$

SD Muhammadiyah Karangbendo Yogyakarta merupakan sekolah yang dapat dikategorikan sekolah yang cukup bagus, dimana sekolah tersebut memiliki sarana dan prasarana yang cukup memadai untuk digunakan dalam melancarkan proses pembelajaran. Kemudian guru-gurunya sangat terampil dalam mengembangkan materi pembelajaran.

Adapun yang menarik perhatian peneliti untuk melakukan penelitian di sekolah ini adalah siswa-siswinya yang terlihat aktif, semangat dan banyak bergerak ketika berada di

\footnotetext{
${ }^{2}$ Desmita, Psikologi Perkembangan Peserta Didik, (Bandung: PT. Remaja Rosdakarya, 2012), hlm. 80.

${ }^{3}$ Maslichatoen, Metode Pengajaran di Taman Kanak-Kanak, (Malang: Departemen Pendidikan dan Kebudayaan, 2006), hlm. 27.

${ }^{4}$ Suyadi dkk, Perkembangan Fisik-Motorik Siswa Usia Sekolah Dasar: Masalah dan Perkembangannya, Jurnal Ilmiah PGMI, Vol 4, No. 2, Desember 2018, hlm.170-182. 
dalam kelas maupun di luar kelas ketika jam istirahat, banyak terlihat anak-anak perempuan bermain lompat tali, lari-larian dan anak laki-laki bermain bola dan ada juga yang saling kejar dan beberapa anak sedang memainkan permainan bermain peran. Kemudian ada juga yang sedang melakukan sholat Dhuha karena sholat Dhuha merupakan kegiatan sekolah yang tidak diwajibkan akan tetapi menjadi pembiasaan untuk semua siswa. Maka berdasarkan hal tersebut, peneliti ingin melakukan penelitian di sekolah ini untuk mengetahui perkembangan fisik motorik siswa dan proses pembelajaran yang berlangsung di dalam kelas sehingga dapat melahirkan siswa-siswi yang aktif, rajin dan semangat.

Permasalahan tersebut menjadi fokus peneliti untuk memecahkan permasalahan terkait dengan perkembangan fisik motorik anak usia sekolah dasar. Adapun penjabaran permasalahan yang peneliti dapat selesaikan adalah (1) bagaimana perkembangan fisik pada anak usia sekolah dasar ?, (2) bagaimana perkembangan motorik pada anak usia sekolah dasar?, dan (3) bagaimana perkembangan fisik motorik pada anak usia sekolah dasar?.

\section{LANDASAN TEORI}

1. Perkembangan Fisik Anak Usia Sekolah Dasar

Manusia terdiri dari fisik dan psikis, fisik merupakan tempat berkembangnya berbagai perkembangan dalam diri manusia. Di dalam fisik selalu terjadi perkembangan kognitif, sosial, moral, agama, dan bahasa. Fisik manusia berkembang dalam beberapa tahapan, yaitu dimulai dari masa anak-anak, remaja, dewasa, dan usia lanjut. ${ }^{5}$

Agoes Dariyo mengatakan bahwa suatu perubahan yang paling menonjol dan nampak di dalam diri individu adalah terjadinya perubahan fisik. Fisik atau tubuh manusia merupakan sistem organ yang kompleks dan sangat mengagumkan. ${ }^{6}$

Secara garis besarnya, pertumbuhan dan perkembangan fisik peserta didik dapat dibagi menjadi tiga tahap yaitu tahap setelah lahir hingga usia tiga tahun, kemudian tahap anak-

${ }^{5}$ Masganti, Perkembangan Peserta Didik, (Depok: Premadamedia Group Kencana, 2017), hlm.67 hlm.43.

${ }^{6}$ Agoes Dariyo, Psikologi Perkembangan Anak Tiga Tabun Pertama, (Bandung: PT. Refika Aditama, 2007), 
anak hingga masa prapubertas (3-10 tahun), tahap pubertas (10-14 tahun), dan tahap remaja/adolescence (usia 12 tahun ke atas). ${ }^{7}$

Perkembangan fisik menurut Kuhlen dan Thompos, dalam Syamsul Yusuf LN, mengemukakan bahwa perkembangan fisik individu meliputi empat aspek yaitu sistem syaraf, otot-otot, kelenjar endokrin dan struktur fisik/tubuh. ${ }^{8}$ Bagi anak-anak usia sekolah dan remaja, pertumbuhan dan perkembangan fisik yang optimal sangat penting, sebab pertumbuhan dan perkembangan fisik anak secara langsung atau tidak langsung akan mempengaruhi perilakunya sehari-hari. Secara langsung pertumbuhan fisik anak akan menentukan keterampilan anak dalam bergerak. Sedangkan secara tidak langsung, pertumbuhan dan perkembangan fisik akan mempengaruhi cara anak memandang dirinya sendiri dan orang lain. Ini akan terlihat dari pola penyesuaian diri anak secara umum ketika berada di lingkungan sekitar mereka.

\section{Perkembangan Motorik Anak Usia Sekolah Dasar}

Pada usia sekolah, perkembangan motorik anak lebih halus, lebih sempurna, dan terkoordinasi dengan baik, seiring dengan bertambahnya berat dan kekuatan badan anak. Anak-anak terlihat sudah mampu mengontrol dan mengoordinasikan gerakan anggota tubuhnya seperti menggerakkan tangan dan kaki dengan baik. Otot-otot tangan dan kakinya sudah mulai kuat, sehingga berbagai aktivitas fisik seperti menendang, melompat, melempar, menangkap dan berlari dapat dilakukan secara lebih akurat dan cepat. Di samping itu, anak juga semakin mampu menjaga keseimbangan badannya. Penguasaan badan, seperti membongkok melakukan bermacam-macam latihan senam serta aktivitas olah raga berkembang pesat. Mereka juga mulai memperlihatkan gerakan-gerakan yang kompleks, rumit, dan cepat, yang diperlukan untuk menghasilkan karya kerajinan yang bermutu bagus atau memainkan instrumen musik tertentu. ${ }^{?}$

Untuk memperhalus keterampilan-keterampilan motorik mereka anak-anak terus melakukan berbagai aktivitas fisik. Aktivitas fisik ini dilakukan dalam bentuk permainan yang kadang-kadang bersifat informal, permainan yang diatur sendiri oleh anak, seperti permainan umpet-umpetan, dimana anak menggunakan keterampilan motornya,

7Desmita, Psikologi Perkembangan Peserta Didik, hlm.74.

8Syamsul Yusuf LN, Psikologi Perkembangan Anak \& Remaja, (Bandung: PT. Remaja Rosdakarya, 2004), hlm. 101.

${ }^{9}$ Desmita, Psikologi Perkembangan Peserta Didik, hlm.79-80. 
disamping itu, anak-anak juga melibatkan diri dalam aktivitas permainan olahraga yang bersifat formal, seperti olahraga senam, berenang, atau permainan hoki. ${ }^{10}$

3. Tahap Perkembangan Belajar Anak Sekolah Dasar

Tahap perkembangan tingkah laku belajar siswa usia sekolah dasar sangat dipengaruhi oleh aspek dari dalam dirinya dan lingkungan yang ada di sekitarnya. Kedua hal tersebut tidak mungkin dipisahkan karena memang proses belajar terjadi dalam konteks interaksi diri siswa dengan lingkungannya. Dari interaksi itu kemudian terbentuk suatu kebiasaan baik yang akan terus dilakukan sebagai upaya dalam pembiasaan diri.

Anak pada usia sekolah dasar (7-11 tahun) berada pada tahapan operasional konkret. Pada rentang usia ini tingkah laku anak yang tampak yaitu anak mulai memandang dunia secara objektif, bergeser dari satu situasi ke situasi lain kemudian anak juga mulai berfikir secara operasional yang dibuktikan dengan anak tersebut mampu mengklasifikaiskan benda-benda disekitarnya. Dimana juga dalam fase ini anak sudah pintar memahami konsep substansi, panjang, lebar, luas, tinggi, rendah, ringan dan berat.

Kecendrungan belajar anak usia sekolah dasar memiliki tiga ciri yaitu konkret, integratif dan hierarkis. Konkret dalam proses pembelajaran mengandung makna yang dapat dilihat, didengar, dibaui, diraba dan diotak atik, dengan titik penekanan pada pemanfaatan lingkungan sebagai sumber belajar yang dapat dioptimalkan demi mencapai proses dan hasil belajar yang berkualitas, bermakna dan bernilai. Hakikatnya anak usia sekolah dasar belum mampu memilah-milih konsep dari berbagai disiplin ilmu, hal ini menunjukkan cara berfikir deduktif yakni dari hal umum menuju hal yang khusus.

\section{METODE PENELITIAN}

Penelitian ini merupakan penelitian kualitatif deskriptif yang bertujuan untuk mendiskripsikan hasil-hasil penelitian yang sesuai dengan fakta yang terjadi di lapangan. Pengumpulan data dalam penelitian ini menggunakan teknik observasi, wawancara dan dokumentasi. Ketiga teknik ini digunakan sebagai solusi untuk menjawab permasalahan yang memerlukan pemahaman secara mendalam. Selain itu penelitian ini menggunakan

${ }^{10}$ Desmita, Psikologi Perkembangan Peserta Didik, hlm. 81. 
pendekatan descriptive research yang memiliki tujuan untuk menjelaskan fenomena atau kejadian yang ada di lapangan. Subjek penelitian ini yaitu para siswa kelas VI A yang terdiri dari 28 orang siswa. Sedangkan teknik analisis data didalam penelitian ini menggunakan analisis sebelum kelapangan dan analisis dilapangan dengan model Miles and Hubermen yang meliputi data Reduction, data display dan conclusion drawing.

\section{HASIL PENELITIAN DAN PEMBAHASAN}

\section{Hasil Penelitian}

\section{Perkembangan Fisik Anak Usia Sekolah Dasar}

Berdasarkan hasil pengamatan yang telah dilakukan pada kelas VI A terlihat bahwa terdapat 3 perbedaan fisik anak, diantaranya ada anak yang pertumbuhan badannya lebih besar dari anak yang lain, ada juga anak yang pertumbuhan badannya lebih lambat yang dimana badannya lebih kecil dari orang lain, kemudian ada beberapa anak memiliki tinggi badan normal yang sepadan dan sesuai dengan pertumbuhan umur mereka.

Terlihat jelas juga aktivitas mereka ketika di dalam kelas. Anak yang memiliki badan besar merasa dirinya dapat memimpin teman-temannya yang lain dia terlihat senang menyuruh temannya untuk mengambilkan barang-barang yang dia butuhkan, kemudian anak yang badannya lebih kecil ini memiliki keaktifan yang luar biasa dimana mereka tidak bisa hanya duduk diam mengerjakan tugas di meja masing-masing akan tetapi mereka sering berkeliling dan mengamati temannya yang lain. Selain itu anak yang memiliki badan yang sepadan memiliki kegiatan yang berbeda-beda, ada yang sedang menulis, ada yang sedang mengajar temannya dan ada pula yang sedang mengobrol sambil mengerjakan tugas.

\section{Perkembangan Motorik Anak Usia Sekolah Dasar}

Setelah melakukan pengamatan di lapangan bahwasanya dalam proses pembelajaran beberapa siswa terlihat melakukan gerakan-gerakan tubuh yang menandakan bahwa mereka telah memahami pelajaran yang diberikan dan adapula beberapa anak yang bertanya kepada gurunya kemudian ada juga anak yang terlihat diam dan murung dikursi tanpa melihat aktivitas temannya. Terlihat jelas bahwa memang benar bahwa setiap anak memiliki perkembangan fisik dan motorik yang berbeda-beda. 
Berdasarkan hasil observasi, terlihat bahwa semakin bagus perkembangan fisik motorik anak, maka semakin mampu anak mengendalikan dirinya untuk melakukan gerakangerakan tubuh yang dapat terkoordinir dengan baik. Seperti contohnya pada saat peneliti masuk ke dalam kelas ketika proses pembelajaran sedang berlangsung, siswa kelas VI A tersebut memiliki tingkat kesadaran yang tinggi terhadap orang baru dan mampu mengkoordinir gerak tubuhnya dengan baik yaitu dengan cara menunjukkan sikap hormat yang tinggi dengan cara menundukkan kepala dan tersenyum dengan ramah.

\section{Perkembangan Fisik Motorik Anak Usia Sekolah Dasar}

Berdasarkan hasil penelitian yang telah dilakukan di lapangan pada hari senin 23 September 2019 dalam proses belajar siswa kelas VI A di SD Muhammadiyah Karangbendo dalam mata pelajaran PAI diperoleh data bahwa mereka melakukan kegiatan belajar atau bermain dengan cara mengelompokkan diri, peneliti dapat melihat ada 5 kelompok perkembangan anak.

Kelompok pertama, yaitu anak-anak yang sudah terlihat memasuki masa pubertas dimana mereka sudah mulai bisa merawat diri kemudian dari segi gerak geriknya sangat dijaga agar mereka terlihat gagah dan rapi. Kelompok kedua, adalah anak-anak yang lebih suka bermain daripada belajar yang terlihat ketika dalam proses pembelajaran mereka mendengarkan materi yang disampaikan oleh guru, namun masih terus bermain sambil berbisik-bisik dengan teman disampingnya kemudian tertidur tanpa merasa bahwa mereka sedang belajar.

Kelompok ketiga, adalah anak-anak yang memang pemalu, jarang bergerak, mereka hanya duduk diam sambil mendengarkan guru menjelaskan pelajaran dan ketika guru bertanya kepada mereka apakah sudah mengerti dengan materi yang disampaikan mereka hanya diam dan menunduk.

Kelompok anak yang keempat yaitu kelompok anak-anak yang duduk di depan, mereka adalah anak-anak yang dapat dikategorikan sebagai anak-anak yang berprestasi di kelas. Hal ini dapat kami lihat ketika guru bertanya, dengan antusias mereka mengangkat tangan dan menjawab pertanyaannya dengan baik.

Untuk kelompok yang terakhir yaitu kelompok kelima, adalah kelompok anak yang memiliki kemampuan menerima pelajaran sangat lambat dari teman lainnya, ketika peneliti 
mengamati proses pembelajaran terlihat bahwa ada anak yang memang duduk diam melihat ke depan akan tetapi tidak memperhatikan, tidak ada respon gerak tubuh atau mata yang menunjukkan bahwa anak tersebut mengerti tentang pelajaran yang guru sampaikan. Tatapan mata mereka kosong seakan melihat kedepan akan tetapi tidak memperhatikan dan tidak mengerti pelajaran yang telah diajarkan oleh gurunya.

\section{Pembahasan}

\section{Perkembangan Fisik Anak Usia Sekolah Dasar}

Dalam buku Rini Hildayani, ia menyatakan bahwa perkembangan fisik adalah pertumbuhan dan perubahan yang terjadi pada tubuh seseorang. ${ }^{11}$ Perubahan yang paling jelas terlihat adalah perubahan pada bentuk dan ukuran tubuh seseorang. Berdasarkan hasil pengamatan yang dilakukan pada kelas VI A, terlihat bahwa terdapat 3 perbedaan fisik anak, diantaranya ada anak yang pertumbuhan badannya lebih besar dari anak yang lain, ada juga anak yang pertumbuhan badannya lebih lambat yang dimana badannya lebih kecil dari orang lain, kemudian ada beberapa anak memiliki tinggi badan yang sepadan.

Desmita menyatakan dalam bukunya bahwa, dalam memperhalus keterampilan motorik anak akan melakukan berbagai macam aktivitas fisik. ${ }^{12}$ Aktivitas fisik ini dilakukan dalam bentuk permainan yang kadang-kadang bersifat informal, permainan yang diatur sendiri oleh anak, seperti permainan umpet-umpetan, dimana anak menggunakan keterampilan motornya, disamping itu, anak-anak juga melibatkan diri dalam aktivitas permainan olahraga yang bersifat formal, seperti olahraga senam, berenang, atau permainan hoki. Jika diamati secara lebih dalam memang terlihat bahwa pertumbuhan fisik mampu membentuk kepribadian anak dalam hal bersosialisasi dengan lingkungan sekitarnya hal ini dapat kami lihat langsung berdasarkan keadaan yang terjadi di kelas VI A SD Muhammadiyah Karangbendo Yogyakarta.

\section{Perkembangan Motorik Anak Usia Sekolah Dasar}

Perkembangan motorik merupakan perkembangan dari segala bentuk perubahan yang terjadi secara progresif pada kemampuan anak untuk dapat melakukan berbagai gerakan yang diperoleh melalui interaksi antara faktor kematangan (maturation) dan latihan atau pengalaman (experiences) selama kehidupan yang dapat dilihat melalui

${ }^{11}$ Rini Hildayani, Psikologi Perkembangan Anak, (Tangerang: Universitas Terbuka, 2016), hlm.34

${ }^{12}$ Dasmita, Psikologi Perkembangan Peserta Didik, hlm. 80 
perubahan/pergerakan yang dilakukan. Pemahaman terhadap pekembangan fisik dan Motorik dapat memberikan manfaat yang besar dalam pendidikan, sehingga guru sebaiknya harus memperhatikan perbedaan fisik-motorik siswa mulai sejak dalam merencanakan pembelajaran. Dalam kegiatan ini jika seorang guru memahami tahap perkembangan fisik motorik peserta didiknya, maka pendidik akan lebih mudah dalam menyusun materi pelajaran yang sesuai dengan perkembangan fisik motorik peserta didiknya. Dengan begitu upaya untuk meningkatkan kualitas pendidikan yang lebih efektif dan efisien dapat berjalan dengan tepat.

Setelah melakukan pengamatan di lapangan bahwasanya dalam proses pembelajaran, terlihat ada beberapa siswa melakukan gerakan-gerakan tubuh yang menandakan bahwa mereka telah memahami pelajaran yang diberikan dan adapula beberapa anak yang bertanya kepada gurunya, kemudian ada juga anak yang terlihat diam dan murung di tempat duduknya tanpa melihat aktivitas temannya. Terlihat jelas bahwa memang benar bahwa setiap anak memiliki perbedaan perkembangan fisik dan motorik.

Hal tersebut sejalan dengan penelitian Tri Murti, yang menerangkan bahwa keterampilan motorik anak sekolah dasar, seiring dengan pertumbuhan fisiknya. Mereka sudah mampu mengendalikan dirinya untuk melakukan keterampilan-keterampilan motorik yang lebih terkoordinir. Mereka sudah mampu melakukan keterampilan motorik kasar seperti melempar bola, menangkap bola, berlari, berdiri di atas satu kaki, melompat, mengendarai sepeda dan berenang. Mereka juga sudah mampu melakukan motorik halus, seperti menulis, menggambar dan menyulam atau menjahit. ${ }^{13}$

Seperti dijelaskan pada teori di atas, yaitu ketika fisik motorik anak semakin tumbuh dan berkembang maka anak akan semakin mampu mengendalikan dirinya untuk melakukan gerakan-gerakan tubuh yang dapat terkoordinir dengan baik seperti pada hasil pengamatan yang telah dilakukan terlihat bahwa ketika dalam proses pembelajaran sebagian besar siswa kelas VI A memiliki tingkat kesadaran yang tinggi terhadap orang baru yang dimana ketika peneliti masuk kedalam kelas anak-anak tersebut mampu mengkoordinir gerak tubuhnya

${ }^{13}$ Tri Murti, Perkembangan Fisik Motorik Dan Perseptual Serta Implikasinya Pada Pembelajaran di Sekolah Dasar, Jurnal Wahana Sekolah Dasar, ISSN: 0854-8293, 2018. hlm 21-28. 
dengan baik yaitu dengan cara menunjukkan sikap hormat yang tinggi dengan cara menundukkan kepala dan tersenyum dengan ramah.

Hasil observasi di atas dapat diperkuat dengan hasil wawancara yang telah dilakukan di lapangan, bahwa anak-anak memang benar menerapkan sikap hormat terhadap kami yang berkunjung di kelas tersebut. Sedangkan dari segi pemahaman siswa terhadap materi pembelajaran yang disampaikan bahwa siswa kelas VI A cukup mampu menangkap dengan cepat materi yang telah diajarkan oleh guru. Penelitian Andryani tahun 2017 pun menunjukkan hal yang sama, yaitu proses pembelajaran berdampak positif terhadap perkembangan fisik motorik. ${ }^{14}$

\section{Perkembangan Fisik Motorik Anak Usia Sekolah Dasar}

Perkembangan fisik adalah pertumbuhan dan perubahan yang terjadi pada tubuh seseorang. Perubahan yang paling jelas terlihat adalah perubahan pada bentuk dan ukuran tubuh. Sedangkan Perkembangan motorik merupakan perkembangan dari segala bentuk perubahan yang terjadi secara progresif pada kemampuan anak untuk dapat melakukan berbagai gerakan yang diperoleh melalui interaksi antara faktor kematangan (maturation) dan latihan atau pengalaman (experiences) selama kehidupan yang dapat dilihat melalui perubahan/pergerakan yang dilakukan.

Sehingga untuk memperhalus keterampilan-keterampilan motorik, anak-anak terus melakukan berbagai aktivitas fisik. Aktivitas fisik ini dilakukan dalam bentuk permainan yang kadang-kadang bersifat informal, permainan yang diatur sendiri oleh anak, seperti permainan umpet-umpetan, dimana anak menggunakan keterampilan motornya, disamping itu, anak-anak juga melibatkan diri dalam aktivitas permainan olahraga yang bersifat formal, seperti olahraga senam, berenang, atau permainan hoki. ${ }^{15}$

Pada saat observasi di kelas VI SD Muhammadiyah Karangbendo pada mata pelajaran PAI, guru membagikan puzæle dengan tema Kemuhammadiyahan. Pada puzzle tersebut terdapat gambar tentang lagu tapak suci, dalam penjelasan guru, anak-anak disuruh untuk merangkai puzzle tersebut agar sesuai dengan contoh gambar yang telah disediakan dipapan tulis. Pada saat membagikan puzzle, guru menyebutkan satu persatu nama siswa, kemudian

${ }^{14}$ Andryani Esti Wibowo, Pengaruh Pembelajaran Sains Terhadap Perkembangan Fisik Motorik Pada Anak Kelompok B Di Tk Desa Kateguhan 02 Kabupaten Sukoharjo Tahun Ajaran 2016/2017, Skripsi Pendidikan Guru Anak Usia Dini, Universitas Muhammadiyah Surakarta, 2017

${ }^{15}$ Desmita, Psikologi Perkembangan Peserta Didik, hlm. 81. 
siswa yang disebutkan namanya maju ke depan untuk mengambil puzzle mereka masingmasing. Sebelum guru menyuruh mereka merangkai puzzle terlebih dahulu guru mengajak anak-anak menyanyikan lagu tapak suci secara bersama-sama dan dengan antusias semua siswa berdiri dan bergerak sesuai dengan intonasi lagu tersebut. Setelah selesai bernyanyi barulah siswa diterangkan tentang penanaman nilai lagu tapak suci dalam diri mereka sebagai bentuk pengabdian kepada sekolah. Dari pembelajaran tersebut peneliti dapat melihat bagaimana perkembangan fisik motorik mereka dalam proses pembelajaran.

Berdasarkan perkembangan fisik motorik mereka dalam proses pembelajaran, terdapat 5 kelompok perkembangan anak, yaitu kelompok pertama yaitu anak-anak yang sudah terlihat memasuki masa pubertas dimana mereka sudah mulai bisa merawat diri kemudian dari segi gerak geriknya sangat dijaga agar mereka terlihat gagah dan rapi. Untuk kelompok yang kedua adalah anak-anak yang lebih suka bermain daripada belajar yang dimana terlihat ketika dalam proses pembelajaran mereka mendengarkan namun masih terus bermain sambil berbisik-bisik dengan teman disampingnya kemudian tertidur tanpa merasa bahwa mereka sedang belajar. Untuk kelompok yang ketiga adalah anak-anak yang memang pemalu, jarang bergerak mereka hanya duduk diam sambil mendengarkan guru menjelaskan pelajaran dan ketika guru bertanya kepada mereka apakah sudah mengerti dengan materi yang disampaikan mereka hanya diam dan menunduk. Adapula untuk kelompok anak yang keempat yaitu kelompok anak-anak yang duduk didepan, mereka adalah anak-anak yang dapat dikategorikan anak-anak yang berprestasi di kelas, dapat kami lihat ketika guru bertanya dengan antusias mereka mengangkat tangan dan menjawab pertanyaan dengan baik. Untuk kelompok yang terakhir yaitu kelompok anak yang memiliki kemampuan menerima pelajaran sangat lambat dari teman lainnya, ketika peneliti mengamati proses pembelajaran terlihat bahwa ada anak yang melihat kedepan akan tetapi terlihat bahwa tidak ada respon gerak tubuh atau mata yang menunjukkan bahwa anak tersebut mengerti apa yang guru sampaikan tatapan mereka kosong seakan melihat ke depan tetapi tidak memperhatikan.

Setelah pembelajaran selesai kami melakukan wawancara dengan guru yang mengajar dikelas VI A. Kami bertanya tentang anak yang terlihat lambat dalam belajar, guru tersebut kemudian menjelaskan bahwa memang benar anak itu memiliki perkembangan kognitif 
yang lambat, karena anak tersebut sudah pindah sekolah berkali-kali disebabkan oleh dia pernah tidak naik kelas 3 tahun berturut-turut. Kegiatan wawancara itu berlanjut dengan cerita beliau tentang siswa tersebut yang berkali-kali mendaftarkan diri ke sekolah lain akan tetapi banyak sekolah yang menolaknya karena tidak berani mengambil resiko terhadap anak yang memiliki keterlambatan tersebut. Akan tetapi karena kesadaran atas kewajiban dalam mendidik akhirnya beliau dengan senang hati menerima siswa tersebut, beliau menjelaskan bahwa kita sebagai guru tidak hanya mendidik siswa yang akan mampu memahami pelajaran dengan baik akan tetapi semua anak berhak mendapatkan pendidikan begitupun dengan anak ini, dan disamping itu siswa yang seperti mereka bisa menjadi tantangan untuk guru-guru dan lembaga yang dimana jika mereka berhasil membuat anak ini lebih baik lagi dan lulus maka otomatis mereka dapat dikatakan sudah berhasil dalam mendidik.

Setelah memahami penyebab dari anak yang memiliki pandangan kosong tersebut. Peneliti juga bertanya tentang pengelompokan karakteristik fisik-motorik anak-anak di kelas dan apakah guru merasakan juga bahwa ada perubahan di dalam kelas atau tidak. Menurut beliau memang benar sekali dan bahkan beliaupun sangat menyadari perubahanperubahan tingkah laku siswa mereka baik dari cara mereka bersikap, cara mereka menangani masalah dan cara mereka merespon setiap kegiatan belajar. Lebih lanjut beliau menyampaikan bahwa kita tidak dapat menghentikan proses perkembangan mereka, akan tetapi kita dapat mengarahkan perkembangan mereka untuk ke arah yang positif, yaitu dengan cara terus mengawasi kegiatan-kegiatan yang mereka lakukan dan jika memang kegiatan mereka kurang baik maka kita nasehati dan kita bimbing mereka untuk menjadi lebih baik.

\section{SIMPULAN DAN SARAN}

\section{Simpulan}

Perkembangan fisik adalah pertumbuhan dan perubahan yang terjadi pada tubuh seseorang. Perubahan yang paling jelas terlihat adalah perubahan pada bentuk dan ukuran tubuh. Sedangkan Perkembangan motorik merupakan perkembangan dari segala bentuk perubahan yang terjadi secara progresif pada kemampuan anak untuk dapat melakukan berbagai gerakan yang diperoleh melalui interaksi antara faktor kematangan (maturation) dan 
latihan atau pengalaman (experiences) selama kehidupan yang dapat dilihat melalui perubahan/pergerakan yang dilakukan.

Peneliti dapat menemukan banyak aktivitas siswa diantaranya dalam proses pembelajaran terlihat bahwa aktivitas siswa sangat beragam. Mulai dari bagaimana cara mereka bergerak, bergaul, bertindak dan berinteraksi dengan teman disekitarnya. Kemudian dari keterampilan guru dalam mengembangkan kreativitas anak sehingga dapat menghasilkan anak yang memiliki perkembangan fisik motorik yang mampu beradaptasi dalam lingkungan kelas, sekolah, dan di luar sekolah. Segala kegiatan itu bersifat positif sehingga akan mampu membentuk dan melahirkan siswa yang memiliki kepribadian yang hebat, cerdas, terampil, cakap, kreatif, dan berakhlak mulia.

\section{Saran}

Perkembangan fisik motorik siswa di SD Muhammadiyah Karangbendo Yogyakarta terutama di kelas VI A terlihat bahwa siswa memiliki perkembangan fisik motorik yang cukup bagus yang ditandai dengan keaktifan siswa dalam bergerak dan bertindak. Untuk itu sekiranya guru perlu memberikan pembelajaran yang akan menumbuhkan minat siswa dalam berkreasi sesuai dengan imajinasi mereka. Serta guru dapat mengembangkan media baru yang nanti akan dapat menstimulus aktifitas fisik motorik siswa dalam proses pembelajaran.

\section{DAFTAR PUSTAKA}

Agoes Dariyo, Psikologi Perkembangan Anak Tiga Tahun Pertama, (Bandung: PT. Refika Aditama, 2007).

Andryani Esti Wibowo, Pengaruh Pembelajaran Sains Terhadap Perkembangan Fisik

Motorik Pada Anak Kelompok B Di Tk Desa Kateguhan 02 Kabupaten Sukoharjo

Tahun Ajaran 2016/2017, Skripsi Pendidikan Guru Anak Usia Dini, Universitas Muhammadiyah Surakarta, 2017.

Desmita, Psikologi Perkembangan Peserta Didik, Bandung: PT. Remaja Rosdakarya, 2012.

Masganti, Perkembangan Peserta Didik, Depok: Premadamedia Group Kencana, 2017.

Maslichatoen, Metode Pengajaran di Taman Kanak-Kanak, (Malang: Departemen Pendidikan dan Kebudayaan, 2006) 
Novan Ardy Wiyani \& Barnawi, Format PAUD Konsep, Karakteristik \& Implementasi Pendidikan Anak Usia Dini, (Jogjakarta: Ar-Ruzz Media, 2012).

Rini Hildayani, Psikologi Perkembangan Anak, Tangerang: Universitas Terbuka, 2016.

Suyadi dkk, Perkembangan Fisik-Motorik Siswa Usia Sekolah Dasar: Masalah dan Perkembangannya, Jurnal Ilmiah PGMI, Vol 4, No. 2, Desember 2018, hlm.170-182. Syamsul Yusuf LN, Psikologi Perkembangan Anak \& Remaja, (Bandung: PT. Remaja Rosdakarya, 2004).

Tri Murti, Perkembangan Fisik Motorik Dan Perseptual Serta Implikasinya Pada Pembelajaran di Sekolah Dasar, Jurnal Wahana Sekolah Dasar, ISSN: 0854-8293, 2018. Hlm 21-28. 